\title{
Divinity refracted: extended agency and the cult of Symeon Stylites the Elder
}

\begin{abstract}
In this paper, I suggest that the material evidence for the LateAntique Syrian cult of Symeon Stylites the Elder demonstrates a pre-Cartesian understanding of extended personhood and agency, in contrast to a modern, dualist model of the bounded body. The saint's iconography, souvenir tokens, and pilgrimage site at Qal'at Sem'an are analyzed in turn, in order to explore the ways in which they reflect a deep concern with the performance of ascent in achieving sanctity, and an understanding of the saint as continually present, living on in the distribution of his agency through the material things of his life, particularly his column. It is suggested that the cult was concerned with the animation of matter and the revelation and refraction of divine presence and truth in the world, in a way which questions definitions of living or lived in the study of ancient religions.
\end{abstract}

In the age of the internet, we are increasingly becoming aware of the ways in which people, ideas, and things are intrinsically networked together. More and more often, we look to Google for the storage of information and memories which once had to be learned by rote. Indeed, new models of extended mind have had to be developed in order to explain the ways in which we "think through things" (see, for example: History of Distributed Cognition Project 2014).

Following on from this, sensory and material culture studies have broken away from the Cartesian dualist model which pervaded academic thought of the late 20th century, and which privileges logocentric meaning over materiality and tacit forms of knowledge or epistemologies. ${ }^{1}$ Ecological theory and indigenous thought, alongside technological advances have drawn attention to the

1 On these new developments see, in particular: Barad 2007; Bennett 2010; Coole and Frost 2010; Hamilakis 2013.

Acknowledgment: I would like to thank Georgia Frank, Vladimir Ivanovici, and audiences at the conference "The Spectacle of the Flesh" at the Bibliotheca Hertziana, Rome, in May 2016, and the Department of Religious Studies and Theology at Cardiff University, as well as the Lived Ancient Religion Group, especially Richard Gordon and Anna-Katharina Rieger, for their valuable feedback on earlier drafts of this paper.

Ә Open Access. (C) 2020 Heather Hunter-Crawley, published by De Gruyter. (cc) BY-NC-ND This work is licensed under a Creative Commons Attribution-NonCommercial-NoDerivatives 4.0 International License. https://doi.org/10.1515/9783110557596-014 
distributed nature of the self and the artificiality of a strict boundary between self and world. ${ }^{2}$ This blended model of human existence is not figurative but rather is a material and lived reality. Historians of pre-modern eras, especially the Medieval, Byzantine, and Archaic, have re-discovered their objects of study by removing the modern lens of Cartesian dualism, which is, of course, itself a culturally-situated perspective derived from 17th century French philosophy, and so its application to earlier periods such as Late Antiquity ought at least to be questioned. ${ }^{3}$

In this chapter, I suggest that the material evidence for the Late-Antique Syrian cult of Symeon Stylites the Elder demonstrates a pre-Cartesian understanding of distributed personhood, and thus agency, akin to theories of extended mind and embodiment, and in contrast to a 20th-century, dualist model of bounded self. This case study potentially could be expanded to the LateAntique cult of saints more broadly, from souvenirs to relics and sites of pilgrimage.

\section{Symeon Stylites the Elder, materiality, and agency}

Building on work by Susan Ashbrook Harvey, Patricia Cox-Miller, Bissera Pentcheva and others, I have previously argued that Late-Antique Christians understood materiality differently to the modern West. ${ }^{4}$ Society was broadly informed by the knowledge that the one God is infinite in power and presence; because he inhabits all of his Creation the material world is full of presence and power that can be revealed and made known through correct ritual and embodied behavior, particularly involving the correct use of the senses. We can think of this as akin to the refraction of light through a prism; the source is dispersed into multiple rays, yet each ray is continuous with and leads back to the source. In this way, in Late Antiquity materiality itself was infinite and interconnected,

2 See, for example: Abram 2010; Hodder 2012; Ingold 2000; Malafouris and Renfrew 2010; Todd 2016.

3 This has particularly been the case in the newly emerging discipline of Sensory Archaeology, on which see: Day 2013; Hamilakis 2013; Day and Skeates 2020. Renger and Stellmacher 2010, argue against the application of Cartesian dualism to the life and cult of Symeon Stylites the Elder.

4 See especially: Hunter-Crawley 2012; Hunter-Crawley 2013. Cf. Harvey 2006; Cox-Miller 2009; Pentcheva 2010. 
and had infinite potential to reveal the presence of God in this world, through embodied action and interaction with iconic objects which enabled Christians to see, hear, smell, taste, and touch divine truth.

This notion finds some expression in the Syriac Life of Symeon Stylites the Elder (dated c. 473 CE):

Truly, we all know and are convinced that God is everywhere - in heaven and on earth, on high and in the deep, in the sea and in the abyss, below the earth and above the heavens. There is no place where his divinity is absent, except in humans who do not do his will. Wherever a human calls on him in truth, there he finds him.

(111, trans. Doran 1992, 179)

Symeon was the first stylite saint and lived in the early 5th century in Syria. He was a severe ascetic whose practices culminated in standing atop a sequence of higher columns (up to c. 9 meters) for around 47 years without shelter. A community grew up around the column, and after his death a sanctuary, Qal'at Sem'an was built around it, probably by the emperor Zeno in the late 5th century. Against the emperor Leo's preference for bringing Symeon's body to Constantinople, it was taken to Antioch to act as a miraculous relic and protector of the city (it was later translated, in part, to the column of Daniel the Stylite: Eastmond 1999, 91-92; Life of Daniel Stylites 57, trans. Dawes 1948).

Our evidence for the saint and his cult includes three versions of his biography, ${ }^{5}$ the pilgrimage complex at Qal'at Sem'an (the largest and most famous on the route through northern Syria to the Holy Land, even though it lacked the saint's corpse), and also souvenir dust tokens, made of earth from the locale of the column and stamped with Symeon's image.

These tokens were understood to be highly powerful, particularly in acts of healing. In many ways, they acted as proxies for the healing hand of the saint himself, as argued by Gary Vikan (2003). Vikan has mapped miraculous tales from the Life of Symeon Stylites the Younger onto souvenir tokens of both the elder and younger saint in order to argue that they functioned through a tactile contagion of magical power, from token to pilgrim. This model appears to be based, either directly or indirectly, on James Frazer's The Golden Bough (1913), a work which famously constructed a dichotomy of magical and religious practices grounded in the author's ethnocentric bias, making colonialist assumptions

5 The Life of Saint Simeon Stylites, written by Theodoret of Cyrrhus during the saint's life; the Life and Daily Mode of Living of Blessed Simeon the Stylite by Antonius, of unknown date; and the anonymous Syriac Life of Saint Simeon Stylites, c. 473 CE. Hereafter these are collectively referred to as the Lives, and individually, respectively, as: Theodoret, Life of Saint Symeon; Antonius, Life of Symeon; and the Syriac Life. All are collected and translated in Doran 1992. 
about cultural intelligence based on a notion of Western superiority, and in which Frazer argued that contagion was fundamental to magical principles.

Vikan's model is persuasive and has been influential in scholarship on the cults of both Symeon the Elder and Younger. ${ }^{6}$ However, its basis in Frazer's assumptions is problematic, particularly because this presents a one-directional transmission of supposedly misconceived "magical" power, which degrades in strength and clarity the further one is from the source, rather like a game of "whisper down the lane". The materiality of the token acts as a conduit which can transmit, in part, the healing power of the saint. Once that power reaches its object - the devotee - the power is transferred, but it can go no further; the devotee does not herself become a conduit or continue the process of contagion. The token itself is not inherently powerful, it is simply an intermediary for an act of touch, thus it cannot have any agency or material presence of its own. What is more, the contagion model implies that all tokens of Symeon the Elder and Younger were understood to have been touched by the saint's own hand (helped by the presence of the manufacturer's palm print, as in Fig. 1), but we cannot assume this was always the case, especially of tokens produced or circulated after the saint's death. Indeed, the miraculous healings carried out with

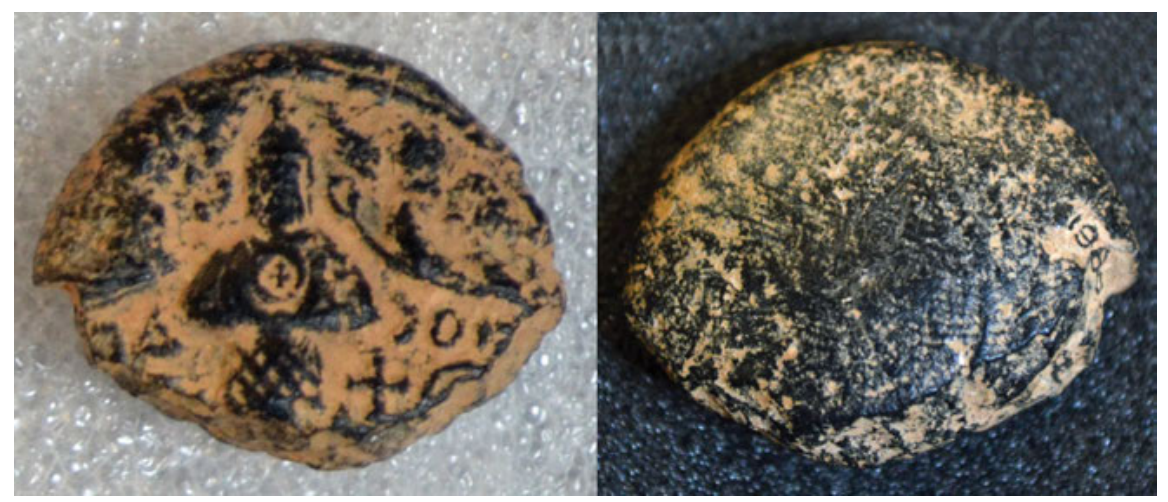

Fig. 1: Souvenir Token of Symeon Stylites the Elder. Left: Obverse. Right: Reverse (with manufacturer's palm print). Clay. 5th-6th C. CE. 23 × $18 \times 8$ mm. Ashmolean Museum, Oxford, AN1980.48A. Photograph: The Author.

6 See, for example, Cox-Miller 2009, 128-129; 146-147, and Eastmond 1999, both of whom share Vikan's assumptions about tactile contagion. 
the saint's dust (termed, in Syriac, his hnana, when mixed with liquid), or with oil or water in his Lives do not necessarily involve tactile contact with the hands of Symeon the Elder. ${ }^{7}$ The biographies inform us that he blesses materials (oil, water, and dust) in his vicinity with the sound of his divine voice (Syriac Life 38; 51, trans. Doran 1992, 123; 133), and instructs petitioners to take the dust or water and rub or pour it on themselves. In this typical example from the Syriac Life, Symeon deals with a boy possessed by demons by instructing him:

\footnotetext{
"In the name of our Lord Jesus Christ, take some of the dust in front of you and rub it all over your body." The boy took it in his hands and rubbed it all over his body. The saint ordered water to be brought and blessed it. The boy took it, drank some of it and poured it over his face. At that moment his reason returned ...
}

(Syriac Life 89, trans. Doran 1992, 168)

In reality, the position of Symeon atop his column imposed tactile distance between saint and worshippers (perhaps even deliberately: Theodoret, Life of Saint Symeon 12, trans. Doran 1992, 75). The sensory experiences of pilgrims in the saint's Lives focus on visual, auditory, and olfactory encounter, that is, the opportunity to see the saint, hear his spoken blessing, and smell his divine stench and fragrance (on which, see Harvey 2006). Direct tactile contact is usually missing, and there is no mention of the production of tokens by the saint atop his pillar. What seems instead to be the most important feature of the tokens is that they were made (or were believed to have been made) from dust from the locale of the saint and his column and enclosure. In this respect, the materiality of the objects themselves is important, and we must account for the agency which they were deemed to possess in effecting healing and miracles.

What I mean by the term "agency" is based on later theorists' development of Alfred Gell's work (1998; cf. Knappett 2005). Gell argued for the active role of objects in culture and human existence, such that our definition of what is animate and inanimate must be expanded beyond the binary limitations of Cartesian dualism (the body as a discrete entity, separate from the world). In this model, animacy necessarily includes not just that which is alive but also those things which enable life to take place. Thus, for example, drinking water keeps us alive and is therefore an integral part of the network of material things which constitute our animate existence as a whole; water is a component of any organism, not conceptually but materially. Equally, if I am to take a glass,

7 As noted above, the stories Vikan 2003 uses to demonstrate this point come from the later Life of Symeon Stylites the Younger. 
fill it with water, and place it in front of me, that glass of water has come to be through my agency, my embodied action and presence in the world, and is therefore part of an extended network of my agency in the environment around me (an environment which, thusly, I have animated and which animates me). We might think of this in terms of the continued sense of a deceased person's presence in the place they once lived, through the things which they have "lived through," or animated (as was the case with the cult of Symeon). Thus, human agency is not limited by the confines of our skin, instead it extends into the environments that we inhabit. In this sense, through our agency we animate the material world around us.

Developing this, archaeological and anthropological theorists such as Knappett have expanded Gell's anthropocentric model by highlighting the active role that things can play in constructing our existence (e.g. Knappett 2005; Knappett and Malafouris 2008). Animacy is constituted through the interactivity of people and things. This conjoins participants in a material network that constitutes an environment, through which their agency is distributed. None of these processes or products are located exclusively in the human body. We can take this further by applying it to understandings of selfhood. Lambros Malafouris (2008a) has argued against the anachronistic retrojection of Cartesian models of self onto archaeological evidence. He notes that, for example, studies of the Homeric self (a model of self-hood which, unlike Cartesianism, pre-dates rather than post-dates Symeon) demonstrate that it fails to conform to modern expectations; the hand of the Homeric hero may cause events, but its agency is often divine. The Homeric body is not a container for a homunculus, it is connected with and distributed among things and its environment. In such a mindset things, bodies, and minds shape each other; the self incorporates its environment and extends beyond the skin. This extended self is not a representational concept but rather the practice of embodiment, and it finds support in cognitive science. The phenomenologist Maurice Merleau-Ponty ([1945] 2002, 165-166), drawing on ancient, medieval, and enlightenment philosophy, explored the idea of the blind person's cane as an instrument through which she or he "sees"; the cane is, in effect, a component of her or his sensory system and self. This is supported by studies of humans and animals which demonstrate that tools are cognitively processed as extensions of the body; the area which can be reached at a distance with a stick is cognitively transformed from extrapersonal to peripersonal space (see e.g. Berti and Frassinetti 2000; Holmes et al. 2004). Malafouris (2008b) terms this "I-as-object"; for the ancient warrior, grasping his sword is an act of incorporation which creates a selfawareness that stretches through to the tip of his sword. Both cognitively and historically, objects can become parts of living bodies. 
In this model, then, selfhood (which, when perceived from someone else's perspective, is personhood) is not necessarily located in a particular human body, but instead is distributed throughout the environment that it inhabits and the things with which it interacts. I suggest that such a model is promising in its potential to reveal the rationale behind the use of Symeon tokens, especially in cases where the saint's direct touch is absent (a problem which destabilizes the essentially Cartesian idea of contagion, in which the saint's body and his world are presumed to be fundamentally distinct, the latter impacting imperfectly on the former through the senses as purely communicative channels). It also promises to address another complication of Symeon's cult, specifically the popularity and success of Qal'at Sem'an as a site of pilgrimage in the complete absence of the saint's corpse. The monumentalization of the site of Symeon's asceticism has been seen as a form of imperial apology for the removal of the saint's bodily relics upon his death to Antioch (Schachner 2010, 358; Sodini 2010), yet it does not make sense to acknowledge so elaborately the absence of a saint. Indeed, evidence indicates that Qal'at Sem'an outlived the success of Symeon's bodily relics, which become lost from the literary records in the 7th century and of which no archaeological record survives, while pilgrimage to the column flourished until the 12th century. ${ }^{8}$ Instead, we must find a way to account for the perception of Symeon's material environment as itself a form of bodily relic. The column, in particular, was clearly understood to be a relic, it was the central focus of a monumental cruciform basilica, and was chipped away over centuries to make souvenirs. The contagion model for the power of the column and the mountain would see both as intermediaries for the saint's touch, and thus as necessarily inferior to the power of the saint's body itself. However, the equal and perhaps greater importance of Qal'at Sem'an in relation to Antioch as a site of pilgrimage for devotees of Symeon suggests that Late-Antique pilgrims thought differently. ${ }^{9}$

8 Eastmond 1999, 90-93. Wright 1970, 83, goes so far as to state: "the column [was] more truly [Symeon's] relic than any part of his physical person".

9 "Certainly even today there are performed healings of all kinds ... not only where his remains lie buried, but also at the monument to his valour and his continual combat ... the great and famous column”, Theodoret, Life of Saint Symeon (interpolation) 28, trans. Doran 1992, 84. Cf. Antonius, Life of Symeon 33, trans. Doran 1992, 100. Interestingly, the corpse was not isolated from another material means of Symeon's asceticism: "Beside the head lies the iron collar, to which, as the companion of its endurance, the famous body has imparted a share of its own divinely-bestowed honours; for not even in death has Symeon been deserted by the loving iron" (emphasis mine), Evagrius Scholasticus, Ecclesiastical History 1.13, trans. Walford 1846. 
I would like, then, to explore the materiality of the cult of Symeon through the lens of agency theory, exploring in turn his iconography, souvenir dust tokens, and finally the site itself.

\section{Symeon as column}

The question of the power of Symeon's column has interested many scholars. Antony Eastmond (1999), for example, has asked why the column was so attractive to devotees, concluding that it functioned like an imperial column, symbolizing authority and power. ${ }^{10}$ However, this does not explain the inherent power of the column as a material object, indeed, while Eastmond cites an example of an imperial column attributed with magical power this post-dates the rise of stylitism, and we may infer an influence of latter to former, rather than vice versa, leaving the power of Symeon's column unexplained. David Frankfurter (1990) has argued that the pillar defined the stylite, and that pre-existing traditions of erecting holy images on pillars (baetyl) authenticated the new form of piety. While this could explain the acceptance of stylitism in Syria, again, the question remains: what was it that made Symeon's column inherently powerful, and how did it relate to the saint's body?

The Syriac Life refers to Symeon as "a firm pillar which arose in our generation" (130, trans. Doran 1992, 195). This conflation of saint and pillar is not purely metaphorical, for it was through the embodied and physical activity of ascent that Symeon "turned [many of the lost] from error to knowledge of the truth" (Syriac Life 3, 106, trans. Doran 1992, 105, 175). Indeed, all three of his Lives abound with references to ascent as the fundamental activity of Symeon's sainthood and divine truth. In Theodoret of Cyrrhus' version, Symeon seeks "the way up", he desires always to stand upright, interpreting sinking to sit or lie down as evidence of weakness; he builds an enclosure so as not to hinder "the flight of the mind"; in prayer he stretches his hands out to heaven, and he exhorts his followers to "look up to heaven and take wing". ${ }^{11}$ Indeed, a great many of Symeon's miraculous healings, in all versions of his Life, cure

10 He assumes that Symeon's corpse was the more important relic (Eastmond 1999, 90-95), though, as indicated above, the evidence does not support this interpretation.

11 Theodoret, Life of Saint Symeon 6, 9, 10, 24, 25, trans. Doran 1992, 72, 73, 74, 82. According to a later interpolation "even after death he remained upright: his soul had gained heaven, but even so his body could not bear to fall”, 28, trans. Doran 1992, 83. 
paralytics, whom he orders, successfully, to "rise up", ${ }^{12}$ while his enemies and detractors are frequently thrown to the ground or paralyzed (Antonius, Life of Symeon 14, trans. Doran 1992, 93; Syriac Life 17, 68, 88, trans. Doran 1992, 113, 149, 167). Antonius, author of the third of the Lives, likewise emphasizes Symeon's practice of praying by "stretching out his hands towards heaven" (Life of Symeon 20, trans. Doran 1992, 96). Harvey (1988; 2006) has shown that the importance of incense in the Syriac Life is symbolically related to the ascent of the saint on his column. ${ }^{13}$ The divine instruction to ascend is a continuous theme in Symeon's visions in the Syriac Life, ${ }^{14}$ and he frequently "lifted his eyes to heaven" (Syriac Life 56, 81, 120, trans. Doran 1992, 136, 162, 189), a gesture which was dictated in a vision and has the power to save those of his followers who mimic it. ${ }^{15}$ Symeon's mission to ascend is also expressed by the church historian Evagrius Scholasticus:

This man, endeavouring to realise in the flesh the existence of the heavenly hosts, lifts himself above the concerns of earth, and, overpowering the downward tendency of man's nature, is intent upon things above: placed between earth and heaven, he holds communion with God, and unites with the angels in praising him; from earth, offering his intercessions on behalf of men, and from heaven, drawing down upon them the divine favour.

(Ecclesiastical History 1.13, trans. Walford 1846)

The essence of Symeon's sainthood lay within the pillar itself, as an instrument of ascent, and without it he would not have been so powerful. The pillar de-

12 Theodoret, Life of Saint Symeon 16, trans. Doran 1992, 78; the upward motion is sometimes continued, for example by climbing a mountain: "on her own feet she walked up the high mountain”, Syriac Life 33, trans. Doran, 1992, 120. See also: Syriac Life 34-35, 38, 80, 81, 83, trans. Doran 1992, 121-123, 161-164.

13 For example, Symeon's prayer: "let the sweet smell [of storax] ascend to God who is in heaven", Syriac Life 2, trans. Doran 1992, 105; and at his shrine "perfumes and chosen spices rise up just as they rose up during his life-time”, Syriac Life 126, trans. Doran 1992, 193.

14 For example, the early vision which "led [Symeon] up the mountain and placed him on top of it”, Syriac Life 4, trans. Doran 1992, 105; and later "he saw a ladder placed on the earth with its top reaching heaven ... A voice was heard calling ... 'Come, ascend'”, Symeon then does the same for those coming after him: Syriac Life 41, trans. Doran 1992, 125-126; his demons, meanwhile, attempt to topple him from his column: Syriac Life 93, trans. Doran 1992, 170, cf. Evagrius Scholasticus, Ecclesiastical History 1.13.

15 By a man who "raised his hands heavenward and lifted his eyes upward", Syriac Life 112, trans. Doran 1992, 181 - a gesture Symeon replicates at his death: Syriac Life 117, trans. Doran 1992, 187. See also Syriac Life 74, trans. Doran 1992, 154. 
fined Symeon's identity both in name ("stylite"; pillar-dwelling; pillar saint) and practice. ${ }^{16}$

Harvey (1988) suggests that Symeon transcended and was transfigured on the pillar, reaching true personhood as a unity of divine and human qualities through his ascent in prayer. He synthesized the parts of his being through the perfect practice of prayer. Similarly, Almut-Barbara Renger and Alexandra Stellmacher (2010) have argued that Symeon's asceticism should be viewed not through a Cartesian lens as the struggle of the divine soul to overcome the material body, but as the exercise and acquisition of embodied knowledge. They argue that in climbing his column, Symeon practiced a means of experiencing the divine which was not accessible or even comprehensible through rational thought. In so doing, he showed the way to heaven, and both he and his biographers incited others to follow his lead through devotees' own bodily practice. This practice was ascent. ${ }^{17}$

It is interesting, then, that the iconographic evidence portrays an inability to separate saint and column. ${ }^{18}$ In a clay token in the Walters Museum, Baltimore (identified by the inscription of the saint's name), Symeon's head is modelled in the shape of an obelisk, by means of his tapering monastic hood (koukoullion) (Fig. 2). This shape is a common feature throughout the iconography of the stylite, expressing both the monumental shape of the pillar and the typical dress of the monk, which crowned the column (compare Figs. 3 and 4). His face is simplistic, identifying this figure as an ascetic saint through the long beard and wide-eyed, frontal stare which crosses the boundary between object and viewer, confronting them with his visual presence and reciprocal gaze. In its minimalist style, the image encapsulates the core aspects of Symeon's sainthood: his asceticism, and his column. These are the aspects which define him.

16 The qualification of Symeon as pillar-dwelling occurs at least as early as Evagrius Scholasticus (Ecclesiastical History 1.13), indicating that such epithets were an established part of the cult from the 5th century. Certainly, those imitators of Symeon (Daniel, Symeon the Younger, and the many others who ascended columns in the Late-Antique Levant - estimated by Schachner 2010 to be c. 27 by the 9th century in Syria alone) perceived ascent as the defining feature of their asceticism. On the terminology and definition of stylites, see Schachner 2010, 332-335.

17 See also Stang 2010 on Symeon's asceticism as a process of descent followed by ascent, which creates a meeting point between underworld, earth, and heaven. Contra Frankfurter 1990, and others, Stang reinstates Drijvers' (1978) argument that Symeon acts in imitatio Christi through his ascent of the column; hence the prevalence of Symeon's iconographic depiction as a cross stationed on top of a column.

18 On Symeon's iconography more generally, see especially: Lassus 1932; Elbern 1965; Peña, Castellana and Fernández 1975; Sodini 1989. 


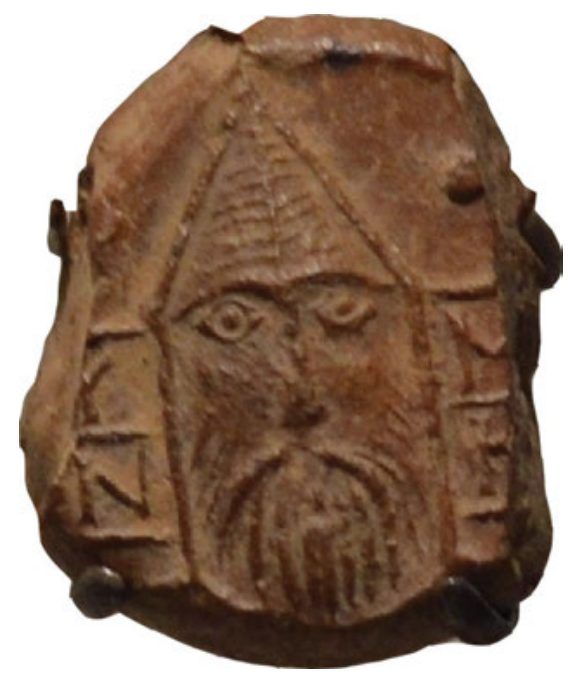

Fig. 2: Souvenir Token with Symeon-ascolumn. Clay. 6th-7th C. CE, $2.9 \times 2.2 \times 1.2 \mathrm{~cm}$. Walters Museum, Baltimore, 48.2666. Photograph: The Author.

A basalt relief from Syria makes similar pictorial choices, again emphasizing the beard, frontal stare, and modelling the saint's body as an obelisk, here with the full length of the column revealed beneath (Fig. 3). The process of ascent is emphasized by the figure of a monk with a censer climbing the ladder. In the act of climbing towards Symeon, he too is becoming column-like; with column-shaped body and pyramidal head, his incongruous arms and feet are the last visible sign that he remains human, for now, caught in a moment of transition from earth towards heaven. The act of etching such figures into solid rock further solidifies their stony, column-like qualities.

Most Late-Antique depictions of Symeon and his fellow stylite saints reflect a similar inability to detach ascetic from the means of asceticism, with columnar bodies and body-like columns a consistent feature. The obverse of the token in Fig. 4 utilizes the most common iconography of a stylite, with pyramidal, bearded head, frontal gaze, and arms holding an object (book or cross) in front of the torso, above a rectangular, fenced parapet on top of a tall, narrow column. As is typical of stylite tokens, the equal proportion of torso to column gives the impression of a standing figure, but on closer inspection we discover that the figure rests not on legs but on a pillar, blurring the edges of the saint's bodily boundaries. The column is a limb, holding the saint upright, and it is this conflation which encapsulates his divine qualities and identifies this figure as a stylite. 


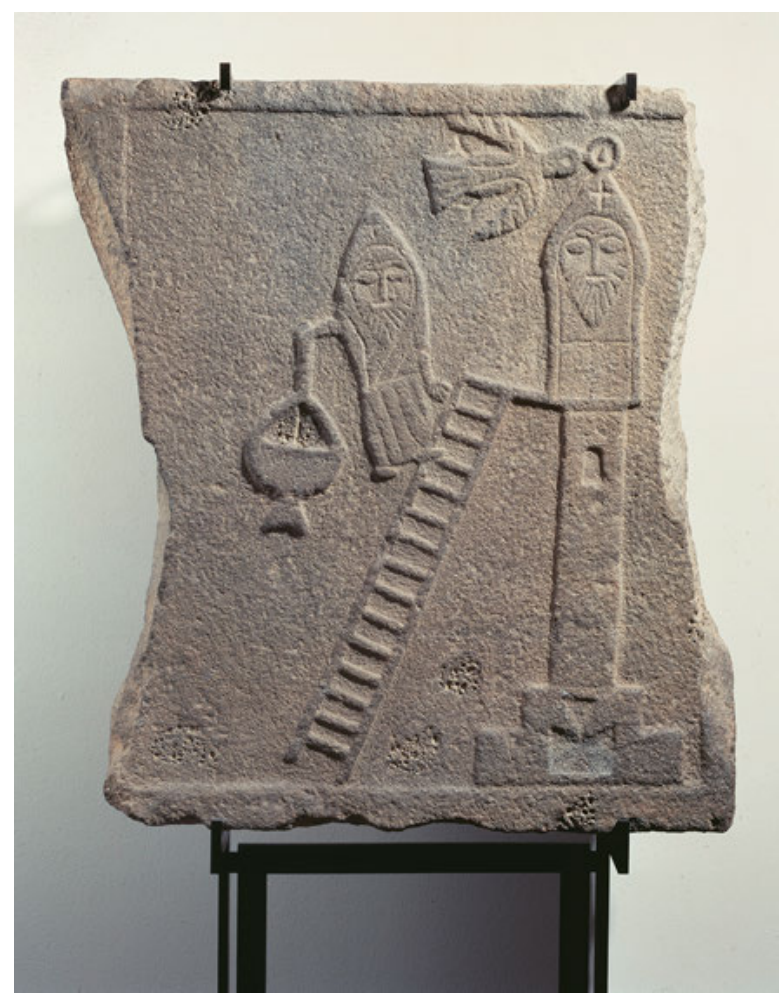

Fig. 3: Basalt Relief of Symeon Stylites the Elder. Syria. 5th-6th C. CE. $84.5 \times 76 \times 18.5 \mathrm{~cm}$. Skulpturensammlung und Museum für Byzantinische Kunst, Staatliche Museen zu Berlin, SBM 9/63. Credit: @ bpk / Skulpturensammlung und Museum für Byzantinische Kunst, SMB / Jürgen Liepe.

The graffito in Fig. 5 is typical of those found on walls in Syria's Dead Cities, the region in which Symeon's column was located. ${ }^{19}$ It, and others like it, abstractly embody the key features of a stylite saint. A tall column, represented by a line, draws the eye up towards a cruciform shape - the appearance of a body praying with its arms outstretched towards heaven, and a symbol of the revelation of divine presence and truth. ${ }^{20}$ Some of the key

19 For further examples, see: Schachner 2010, 370-375; Peña, Castellana and Fernández 1975. Similar designs are also found on glass bottles, so-called "stylite vessels": Evans and Ratliff 2012, no. 62a-c; Sodini 1989, 32.

20 Drijvers 1978 argued that Symeon was understood to act as imitatio crucis. Frankfurter 1990 disagreed, seeing the equation of stylite and crucifix as a later iconographic development, while Stang 2010 has recently reinvigorated the debate by demonstrating how all three of the Lives paint Symeon as imitatio Christi from the cult's very beginning. 


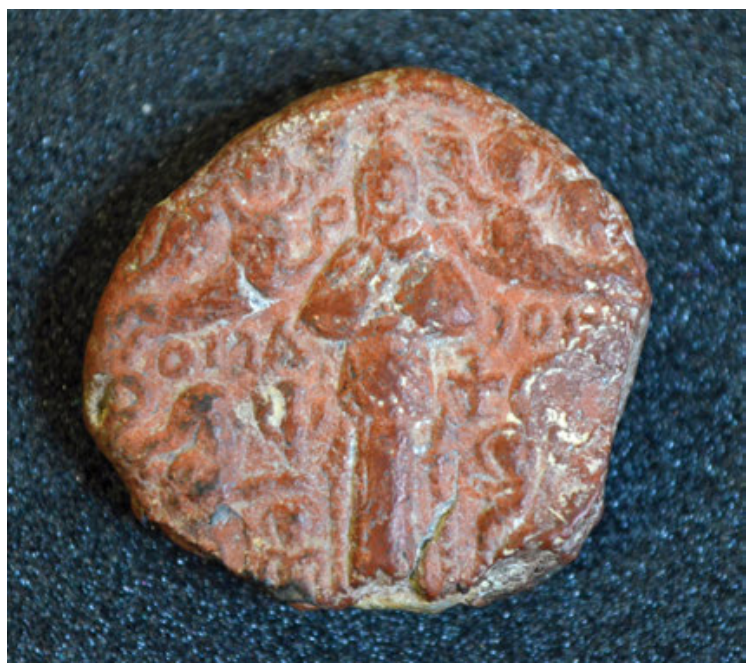

Fig. 4: Souvenir token of Symeon Stylites the Elder. Clay. 5th-6th C. CE. $28 \times 26 \times 7 \mathrm{~mm}$. Ashmolean Museum, Oxford, AN1980.47. Photograph: The Author.

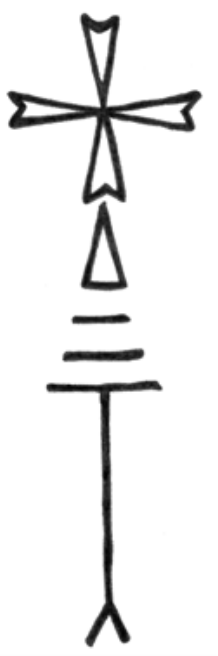

Fig. 5: Graffito from a stable in Dayr Bāshakūh (Jabal Barīshā), northern Syria. Drawing: The Author after Peña, Castellana and Fernández 1975, fig. 77.

features of Symeon's iconography are here stylized: the base of the column; its shaft; the parapet fence; and the tapering peak. Again, the line between body and column is not clearly drawn and it is unclear where one ends and 
the other begins, or, indeed, where the act of asceticism ends and revelation of divine truth begins. The message here is that each equates to the other, and to sever that connection is to negate the divine presence and power which Symeon revealed to the world.

These are just a few examples of many other such representations, which extended beyond Syria. Indeed, Theodoret reports that during Symeon's lifetime, in Rome "portraits of him were set up on a column at the entrances of every shop to bring ... protection and security" (Life of Saint Symeon 11, trans. Doran 1992, 75). ${ }^{21}$ The emphasis on the mode of display suggests that the portraits were ineffective without the columns, and both together created a powerful protective device at a liminal place - the threshold. Comparatively, throughout northern Syria anthropomorphic columns have been found inscribed on doorposts, walls, and columns of Late-Antique and Byzantine churches, stables, and houses. Indeed, the church at Qalb Loze is covered in architectural and inscribed colonettes, capped by cruciform figures (Peña et al. 1975, 190-192; Wright 1970, 98). Stylized graffiti, like that in Fig. 5, is prolific, but we also find further architectural stelae, as in Fig. 3, and reliefs of stylites inscribed on reliquaries, including examples where an incised column extends beneath the hole through which oil, sanctified by the relics inside, was emitted, again indicating an inability to separate body from column (Peña, Castellana and Fernández 1975, 179-202, fig. 31-53; reliquaries: fig. 47-49). In all these instances, which reflect not just the cult of Symeon the Elder but also those of his stylite successors, there is a concerted effort to convey the special power of a human-column hybrid. ${ }^{22}$ Indeed, this is so well-established that times the saint is depicted as simply a head or face perched on top of a column, while at others he radiates or is transfigured into a cross atop the column, and sometimes he is reduced simply to his koukoullion as an upward-pointing triangle which caps the column, emphasizing the process of ascent once again. ${ }^{23}$ To his devotees, the

21 Doran reads "anastelosai" for "anastesai" (Migne, Patrologia Graeca 82, col. 1473). There is also evidence of stylite graffiti in the Domitilla Catacomb in Rome, which parallels the hybrid iconography of northern Syria: Menze 2015, fig. 16.3.

22 Frankfurter (1990, 186), notes the strong iconographic tendency towards an "anthropoid pillar”. See also Lassus 1947, 278-279, 286. Menze (2015, 218), notes the hybrid nature of body and column, but ascribes this to abstract symbolism and a desire for a "catchy picture" (224), failing to acknowledge the material qualities and context of these images, which are etched into the same stony material as the column itself (architectural columns and supports), thereby converting existing architecture into powerful manifestations of stylite power through a form of mimesis.

23 Head: 6th century stele from the Hama Museum, Peña, Castellana and Fernández 1975, fig. 32. Face: stele in the Louvre, Peña, Castellana and Fernández 1975, fig. 33. As a cross: stele from Djibrin, Peña, Castellana and Fernández 1975, fig. 36. Radiating a cross: relief from the 
stylite was understood as a human-column, and the inscription of his image could even transform any ordinary architectural column into that of a stylite.

A frequent feature of stylite iconography, then, are shapes that depict ascent, particularly the pointed obelisk or triangular figure which transform a column into an upward pointing arrow. Like these designs, coils encourage the eye to follow their trajectory upwards, and they, too, feature in the saint's iconography, such as the famous silver votive plaque in the Louvre (BJ2180: Sodini 1989, fig. 19) on which a snake attempts to ascend Symeon's column, drawing the viewer's eye up and along its form towards Symeon at its peak. Serpents had a rich and multivalent religious significance in Antiquity, but perhaps for the creator or dedicator of this plaque the tales of coiling snakes in Symeon's Lives held a particular relevance. ${ }^{24}$

The identity of the shapes on a set of Symeon tokens in the British Museum is debated, with both snakes and mandrake roots suggested (1973,0501.62-67: Camber 1981; Rahmani 1999). However, whatever these objects' precise identity is, they certainly act, like any coiling shape, to draw the eye heavenward, thus reinforcing the theme of ascent in the saint's cult. For pilgrims visiting the site, coiling or circling in crowds around the column was an important ritual. According to Antonius, at the saint's death Ardabur's troops "formed circles around his pillar", and birds "circled round the enclosure” (Life of Symeon 29, trans. Doran 1992, 98), and Evagrius Scholasticus describes men dancing around the column and circulating it (perinostountes) with their beasts of burden on the anniversary of the saint's death (Ecclesiastical History 1.14). ${ }^{25}$ Coiling upwards, whether with eyes or whole bodies, appears to have been an important theme for pilgrims to Qal'at Sem'an. Like the monk in our basalt relief, the embodiment of ascent appears to have offered a path to salvation.

The visual assimilation of the saint's body and column illustrates the contemporary perception that the pillar was as much a part of Symeon's physical presence as his beard and staring eyes. In effect, it was an extension of his body, much like a limb. In the same way that Malafouris' warrior's self

North tower of Qalb Loze church, Peña, Castellana and Fernández 1975, fig. 41. Schematized triangle: Stele from Rasm el Nafel, Peña et al. 1975, fig. 39, cf. a glass amulet from Qal'at Sem’an, Peña, Castellana and Fernández 1975, fig. 45.

24 Snakes often coil around Symeon and his followers, attempting to distract or inhibit them, but the saint exorcizes and uncoils them: Syriac Life 30; 90, trans. Doran 1992, 119; 168.

25 Cf. a tale of Symeon's early asceticism which involved coiling a rope around himself until it became one with his flesh: Antonius Life of Symeon 5-8, trans. Doran 1992, 89; Syriac Life 21, trans. Doran 1992, 114. 
extended to the tip of his sword, so Symeon's sainthood extended into the world through and as the tools of his ascent. For the saint's devotees, to appreciate his power and presence involved not only seeing his face, or hearing his voice, or smelling his divine scent, but it also involved craning one's neck and raising one's eyes heavenward, along and up the column, in order to do so. The iconography of the stylite reveals the perfect marriage of Symeon with his material surroundings, and the synthesis of body and soul which he achieved. He is the column and it is he, and the one without the other is a fragmentary relic of the embodied whole icon. Both body and column had the potential, then, to reveal the saint's agency, and his truth, in equal measure. $^{26}$

\section{Pieces of the mountain, pieces of the saint}

The souvenir tokens of Symeon were composed of his sacred dust, mixed with oil or water from his mountain to make hnana, clay, and then imprinted with the saint's image as a hybrid body-column before being left out to dry in the sun. As we have seen, throughout Symeon's Lives pilgrims are exhorted by the living saint to pour or smear the dust on themselves for healing or to sprinkle it on land or possessions for protection. It is also reportedly used at remote locations to invoke Symeon's protective presence and perform miracles, for example to prevent shipwreck at sea, or to ward off dangerous beasts from one's property (Syriac Life 71-72, trans. Doran 1992, 151-153). These stories reminded devotees that the dust acted as a means for Symeon's holy agency to be materialized away from his mountain; through hnana, Symeon's power was made manifest as if his whole living self were present.

With Cox-Miller $(2009,128)$ we might ask precisely from what Symeon's hnana was composed. She notes that in the Life of Symeon Stylites the Younger the presence and body of the younger Symeon is extended by means of his iconic tokens, though:

26 This is supported by the ensuing practice of burying successive stylites near to their columns, or, in the case of Daniel, the corpse being left standing on top of the column, thereby continuing his ritual of ascent beyond death: Schachner 2010, 358; Life of Daniel Stylites 99, trans. Dawes 1948. For examples of stylite reliquaries, which emphasize the role of the column, see Peña, Castellana and Fernández 1975, fig. 47-49. 
the dust has an ambiguous referent: is it some actual shedding from the saint's real body (an allusion, perhaps, to the creation of human beings from the dust of the earth in Genesis), or is it the dust from around the saint's column, rendered holy due to its contact with Symeon's body and to its use as image-bearing token? (Cox-Miller 2009, 128-129) ${ }^{27}$

There are some problematic assumptions here, firstly that the dust is referential rather than a form of material presence; if the tokens are composed of dust from around the column they do not simply signify that dust at some cognitive remove, they are that very dust. Secondly, in contradiction to the observation that Symeon's body is extended, the conjunction "or" imposes a Cartesian model of self in which the saint's body is distinct from his environment; the dust is either shed from the body or it comes from the ground, empowered through a contagion of touch, and this, as we have seen, is not axiomatic. Thirdly, even if "the dust of the earth" is understood to be flesh, or flesh-like, this does not explain why this very dust constitutes the flesh of this very saint; why is this earth a part of Symeon? Most helpful in illuminating this problem is the geochemical analysis of a set of Symeon tokens purportedly discovered at or near Qal'at Sem'an, which concludes that the soil of the tokens matches that of the site (Gerard et al. 1997). Symeon's hnana was indeed composed from the soil of his mountain.

The earth and water of the mountain from which these tokens were made were part of the environment Symeon inhabited, and, like the column, the mountain itself by means of its height enabled Symeon to enact ascension. Like the column, the mountain was a constituent part of the extended network of Symeon's agency, indeed a constituent part of his sainthood. He revealed divine truth by climbing on top of this very mound of earth, and pilgrims could access the saint's presence within its matter. On the face of his tokens, that is, on their highest points when laid flat, Symeon is imprinted as a column, just as he inhabited the top of the mountain. The token as a whole was a miniature icon of the whole saint, embodying the constituent parts of his personhood: his body and column, as an imprinted image; and the mountain itself, in the very material substance of the token. In this way, the saint was present in this object, as the components of his agency fused with each other and with the wider material network of Symeon's presence on earth. The sight, sound, smell, taste, and touch of the distributed saint were all accessible to devotees through these

27 Steiner 2011 has developed the former suggestion by noting that God created the flesh of Adam from earth and water (clay), thus a concoction of earth and water may have been understood to be flesh. One notes, though, the absence of breath in the tokens' creation, perhaps the most important force of animation in Genesis. 
tiny souvenir objects. ${ }^{28}$ The pilgrim viewed Symeon atop his column, heard the sounds of his name or blessing whenever the inscribed words on the tokens were read aloud, and smelled, touched, and even tasted his ascent in the earthy substance of his mountain. Through their sensory engagement with the object, devotees' bodies re-vivified and re-animated Symeon's presence and truth, ensuring its infinite refraction in the community of the faithful as the reach of a miraculous person extended well beyond the confines of the human body.

The palm prints on many of the surviving tokens (Fig. 1), as highlighted by Vikan (2010), can also be understood to relate to the saint's body. However, this is not a process of contagion, involving diminishing power from the very hand of the original saint, rather we can understand these to be imprints in the same way as the image of the saint is an imprint of the original and the saint himself was an imprint of Christ and divine truth. Divine truth is infinite and cannot diminish in power, thus every imprint is a direct replica, equal in power to the original (see further Hunter-Crawley 2012; Hunter-Crawley 2013). The tokens both replicated and manifested the power of the saint.

\section{Ascending the mountain, embodying the saint}

Finally, I would like to consider the site of Symeon's asceticism more broadly. I have previously explored at length the role of the layout of the pilgrimage site at Qal'at Sem'an in focusing pilgrims' attention on the embodied process and experience of ascent (Hunter-Crawley 2017). The monumentalization of the site conspicuously encourages pilgrims to "rise up", and to "raise their eyes towards heaven", as the saint instructed in his Lives, versions of which would have been read aloud at the site on his saint's day.

The cruciform basilica around the complex (Fig. 6), and perhaps also the column itself, would have been visible from approaching roads for miles around (see Schachner 2010, fig. 15). However, during their ascent of the mountain, the sightlines of the pilgrim were focused and channeled such that the column was not fully revealed until one was directly in front of it. As the pilgrim began to ascend the mountain from the village of Dayr Sem'an at its base, buildings lined the path, enclosing their view, so that the focus was on the climb and not on the surrounding countryside. At the onset of their climb, and

28 On tasting and eating the tokens, see Vikan 2003. Many tokens (including that in Fig. 4) show signs of being scraped by pilgrims to release some of their dust, presumably for curative purposes in the manner of hnana in the saint's biographies, see Pentcheva 2010, 38; Rahmani 1999. 


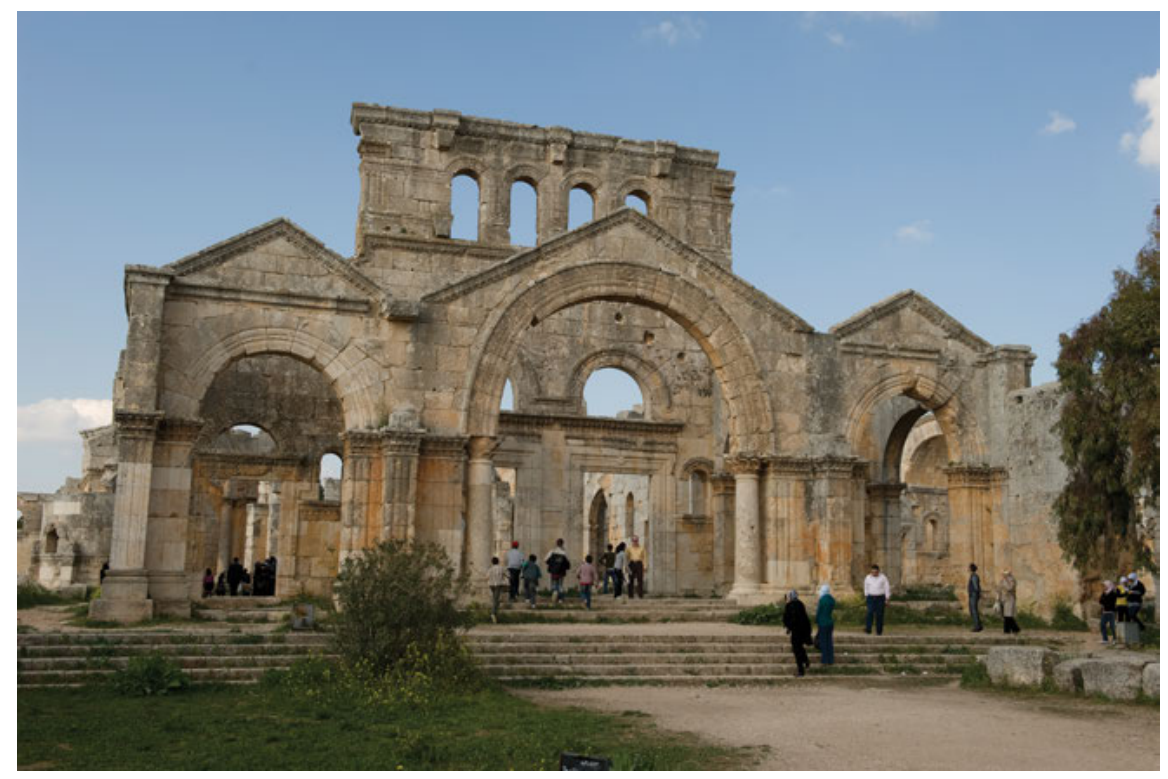

Fig. 6: Southern Entrance to Qal'at Sem'an, Main Basilica. Photograph: Dick Osseman.

just before the path took a sharp turn to the left, they encountered a triumphal arch, supported by and decorated with colonnettes (Fig. 7).

This architectural feature continued throughout the site, and it functioned to draw the eye up the miniature columns and across the sweeping arch, thus priming the pilgrim for the acts of upward vision which were required ahead, and which accompanied the physical climb. The arch also served to narrow the flow of traffic, which, if it was as heavy as Theodoret suggests (Life of Saint Symeon 11-12, trans. Doran 1992, 74-75), would have slowed progress and increased pilgrims' waiting time and sense of anticipation, while offering plenty of opportunity to view the arch itself. ${ }^{29}$

The climb continued to be enclosed along the via sacra, reaching a series of monumentalized gateways, also decorated with colonnettes, which opened onto a sequence of walled terraces sloping uphill (Sodini and Biscop 2011, 19-26). After passing through these (slowly, in heavy traffic), the pilgrim crossed to the church enclosing the column, reaching the fourfold door in its southern basilica (Fig. 6).

29 Hunter-Crawley 2017, 197. Yasin 2017, 170, and Sodini and Biscop 2011, 21, suggest pilgrims were formally registered here. 


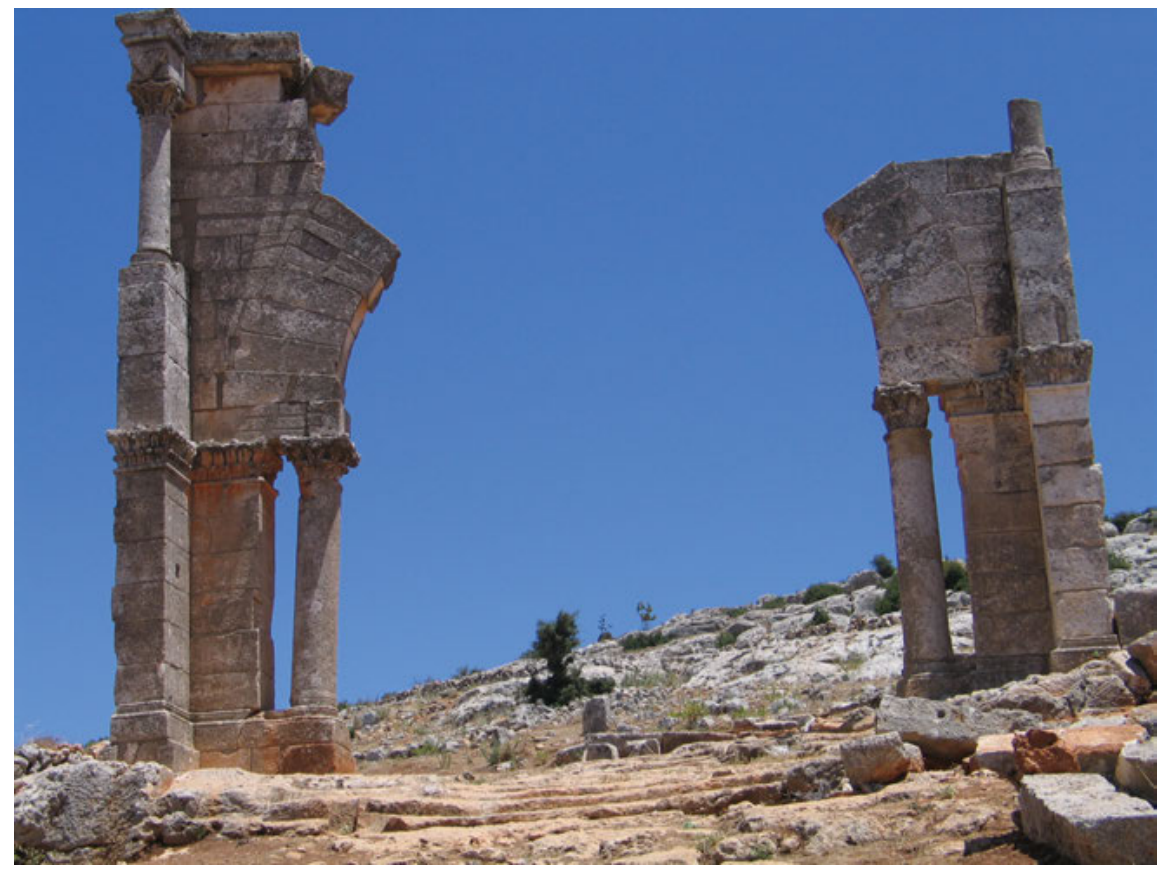

Fig. 7: Triumphal Arch, Dayr Sem'an processional way (base of Symeon's mountain). Photograph: Ann-Marie Yasin.

Again, the choice of a series of arches supported by colonettes here foreshadowed Symeon's column and encouraged the pilgrim's upward gaze. ${ }^{30}$ The arches are perhaps not coincidentally capped with triangular pediments, similar to Symeon's pointed hood (koukoullion), further drawing the eye upward. Climbing the steps and passing through the dim basilica, eventually pilgrims reached the central, octagonal atrium, where the direct, unmediated presence of the column was finally revealed, and they could at last crane their necks to raise their eyes up towards its peak in the open-air above. The pilgrim had mimicked and re-embodied the very activity of the stylite, within the environment that he himself had inhabited, and ascended the mountain, towards heaven.

30 Colonettes are frequently found as decorative features in churches and martyria of northern Syria during this period. The use of colonettes at Qalb Loze church has been identified as an explicit reference to stylitism, see Peña, Castellana and Fernández 1975, 190-192. Votive inscriptions of stylite columns are also commonly found: Peña, Castellana and Fernández 1975, 182-202. 


\section{Paths to salvation: the practice of mimesis, and soul-body synthesis}

The cruciform basilica at Qal'at Sem'an radiates out to the four corners of the earth from the column in its central octagon. We might note, here, a parallel with the iconographic depiction of the stylite as cross atop a pillar (Fig. 5). The layout of the church reflects the shape of the stylite, with arms outstretched to heaven in prayer, and the iconography reflects both church and saint as the revelation of divine truth, extending out into the world. The presence of two baptisteries at the site indicates its importance as a place for baptism, offering opportunity for pilgrims to become immersed in yet more matter imbued with presence - the water of Symeon's mountain, which fell directly from heaven into cisterns (Sodini and Biscop 2011, 26; 33). The font of the southern baptistry sat beneath a canopy, supported by four columns, inside an octagonal tower, architecturally echoing the site's focal point, and likewise channeling the eye towards heaven (Sodini and Biscop 2011, 26-31). ${ }^{31}$ As was the case throughout Qal'at Sem'an and the material culture of Symeon's cult, mimesis with the stylite is here a key feature.

Symeon was understood as an imprint of divine truth, as were his tokens (Theodoret, Life of Saint Symeon 12, trans. Doran 1992, 76). Like all saints and ascetics, Symeon, the living crucifix, was an imitation of Christ himself, who, as Theodoret reminds us, said: "He who believes in me will also do the works that I do, and greater than these will he do" (Theodoret, Life of Saint Symeon 17, trans. Doran 1992, 79; see also above note 20). Symeon revealed and refracted the infinite presence of God in this world, and through his embodied practice of ascent became, as Harvey (1988) has argued, a perfect synthesis of body and soul, heaven and earth. ${ }^{32}$ In this way, Symeon's asceticism was not, as Eastmond suggests $(1999,87)$, a rejection of the body and material world, it was about learning to

31 Late-Antique, northern Syrian baptisteries were usually comprised of a rectangular building and circular font. They frequently imitated the architecture of the church to which they were attached: Peña 1996, 95-101. At Qal'at Sem'an there is a concerted effort to create this same effect, but in that site's international, rather than local style of monumental architecture. While Roman baptistries were commonly octagonal, an octagonal atrium at the centre of a cruciform basilica was an architectural innovation necessitated by the peculiar circumstances of Symeon's new form of ascetism - stylitism. The parallelism between the two buildings would have been striking to contemporary visitors, the specific context obviating a link between the architecture and experiences of ascent. See Sodini and Biscop 2011, 26-31.

32 "Symeon, that angel upon earth, that citizen in the flesh of the heavenly Jerusalem", Evagrius Scholasticus, Ecclesiastical History 1.13, trans. Walford 1846. 
engage with and live in the world in a correct and virtuous way. In the life and cult of Symeon Stylites the Elder, as Renger and Stellmacher (2010) have argued, materiality and ritual practice offered a path to salvation. Pilgrims mimicked Symeon's mode of embodiment, learning it through the physical process of ascent at the very site, imbued with Symeon's agency and continued presence, at which he himself learned and revealed that truth. In this way, they became a mimesis of the saint, as he himself was of Christ, and they too could harmonize body and soul, and reach closer toward heaven. ${ }^{33}$ By inhabiting that same environment as Symeon, and in a similar way, pilgrims even participated in and became components of the network of Symeon's agency, becoming conjoined with him, fellow pilgrims, and the presence of God on earth.

\section{Conclusion}

Symeon's sainthood was not limited to a human body, but rather operated as an extended network, the agency of which could be present in the things that he "lived through" and "with", and which collaborated in his practices of ascent. The column and dust of his holy mountain were a part of Symeon, much as his bones or hair, and continued to manifest his holy agency after his death. Qal'at Sem'an and its material culture did not honor the paradoxical absence of the saint, but rather acknowledged his inherent presence at the locale that he had inhabited for most of his bodily life. The saint lived on in things, and through their senses and embodied actions pilgrims could come to know and understand the divine truth that Symeon continued to reveal and refract into the world - that, as the body ascended upward, heaven could indeed be brought down to earth.

I hope to have shown that models of extended or distributed body and mind, selfhood, and agency can prove helpful in answering certain questions about the value and function of the material culture of Symeon's cult that have challenged previous scholarship. Nonetheless, this study also raises new questions about the Late-Antique cult of saints and relics more broadly. Theories of extended self and the peripheries of the body usually take the perspective of the self as a living being. However, in Symeon's cult we are dealing with a deceased individual who continued to live on through things, and who was perceived to do so by his

33 Theodoret prays that "my own life may be brought into harmony": Life of Saint Symeon 28, trans. Doran 1992, 83. Antonius presents "control of the soul" as the main theme of Symeon's asceticism: Life of Symeon 2, trans. Doran 1992, 87. Symeon as mimesis of Christ: Antonius, Life of Symeon 13, trans. Doran 1992, 92; Theodoret, Life of Saint Symeon 12, trans. Doran 1992, 76. 
followers, whether or not he ascribed to such ideas himself. ${ }^{34}$ This is indicative of the contemporary mindset, one in which new conceptions of the self and definitions of life and death were being developed as Christian cultures evolved. In the evolution of the cult of saints and relics, in which Symeon's innovation played an influential role, Christian society was establishing ideas about the transmutability of the human body, such that it was able to transition between earth and heaven, in life and in death. The saintly, unbounded body helped Christians to make sense of new, challenging concepts of the divine, and offered a prototype of practice for others to follow. In light of this, it is perhaps unsurprising that stylitism flourished in Syria in the centuries following Symeon's death. The material culture of the cult of saints offered a testing ground for the collective exploration of new ideas about the body, and the remains which survive today testify to this activity. The ritualized maintenance of Symeon's column and mountain kept the saint alive through a collective act of memory-making, and this enabled his truth to live on in other human lives, thus perpetuating its refraction and the extension of his (living) presence. In this way, we might say that the embodied practice of Symeon's asceticism offered a prototype for the refraction of the divine through the human, spirit through matter, resulting in eternal life (the hope of many a Late-Antique Christian). It remains to be seen, then, whether the cults of other Late-Antique saints could be understood to have operated in a similar manner, with similar consequences.

\section{Bibliography}

Abram, David 2010. Becoming Animal: An Earthly Cosmology. New York.

Barad, Karen 2007. Meeting the Universe Halfway: Quantum Physics and the Entanglement of Matter and Meaning. Durham.

Bennett, Jane 2010. Vibrant Matter: A Political Ecology of Things. Durham.

Berti, Anna; Frassinetti, Francesca 2000. 'When Far Becomes Near: Remapping of Space by Tool Use', Journal of Cognitive Neuroscience 12. 415-420.

Camber, Richard 1981. 'A Hoard of Terracotta Amulets from the Holy Land.' In Actes du XVe congrès international des études byzantines, Athèns, Septembre 1976: II Art et Archéologie, Communications A. Athens. 99-106.

Coole, Diana H.; Frost, Samantha (eds) 2010. New Materialisms: Ontology, Agency, and Politics. Durham.

Cox-Miller, Patricia 2009. The Corporeal Imagination: Signifying the Holy in Late Ancient Christianity. Philadelphia.

34 Though in refusing to be parted from his column, we might say that Symeon did indeed treat it as a limb. 
Dawes, Elizabeth 1948. Three Byzantine Saints: Contemporary Biographies of St. Daniel the

Stylite, St. Theodore of Sykeon and St. John the Almsgiver. London.

Day, Jo (ed.) 2013. Making Senses of the Past: Toward a Sensory Archaeology. Carbondale.

Day, Jo; Skeates, Robin (eds) 2020. Routledge Handbook of Sensory Archaeology. Abindgon.

Doran, Robert 1992. The Lives of Simeon Stylites. Collegeville, MN.

Drijvers, Hendrik J.W. 1978. 'Spätantike Parallelen zur altchristlichen Heiligenverehrung unter besonderer Berücksichtigung des syrischen Stylitenkultus.' In Erkenntnisse und

Meinungen vol. 2, ed. Gernot Wiessner. Göttinger Orientforschungen 1, Reihe Syriaca.

Wiesbaden. 77-113.

Eastmond, Antony 1999. 'Body Vs. Column: The Cults of St Symeon Stylites.' In Desire and Denial in Byzantium: Papers from the 31st Spring Symposium of Byzantine Studies, ed. Liz James. Aldershot. 87-100.

Elbern, Viktor H. 1965. 'Eine frühbyzantinische Reliefdarstellung des älteren Symeon Stylites', Jahrbuch des Deutschen Archäologischen Instituts 80. 280-304.

Evagrius Scholasticus. 'Evagrius Scholasticus, Ecclesiastical History (AD 431-594), Translated by E. Walford (1846).' Available at: http://www.tertullian.org/fathers/evagrius_1_book1. htm <Accessed 22 April 2009>.

Evans, Helen C.; Ratliff, Brandie (eds) 2012. Byzantium and Islam: Age of Transition, 7th-9th Century. New York.

Frankfurter, David T.M. 1990. 'Stylites and Phallobates: Pillar Religions in Late Antique Syria', Vigiliae Christianae 44. 168-198.

Frazer, James G. 1913. The Golden Bough. Mineola.

Gell, Alfred 1998. Art and Agency: An Anthropological Theory. Oxford.

Gerard, Martine et al. 1997. 'Argiles et Eulogies En Forme de Jetons: Qal'at Sem'an En Est-Il Une Source Possible?' In Materials Analysis of Byzantine Pottery, ed. Henry Maguire. Dumbarton Oaks. 9-24.

Hamilakis, Yannis 2013. Archaeology and the Senses: Human Experience, Memory, and Affect. Cambridge.

Harvey, Susan Ashbrook 1988. 'The Sense of a Stylite: Perspectives on Simeon the Elder', Vigiliae Christianae 42. 376-394.

Harvey, Susan Ashbrook 2006. Scenting Salvation: Ancient Christianity and the Olfactory Imagination. Berkeley.

History of Distributed Cognition Project 2014. 'Seminars.' Available at: http://www.hdc.ed.ac. uk/seminars <Accessed 29 July 2016>.

Hodder, lan 2012. Entangled: An Archaeology of the Relationships between Humans and Things. Oxford.

Holmes, Nicholas P.; Calvert, Gemma A.; Spence, Charles 2004. 'Extending or Projecting Peripersonal Space with Tools? Multisensory Interactions Highlight Only the Distal and Proximal Ends of Tools', Neuroscience Letters 372. 62-67.

Hunter-Crawley, Heather 2012. 'Pilgrimage Made Portable: A Sensory Archaeology of the Monza-Bobbio Ampullae', HEROM: Journal on Hellenistic and Roman Material Culture 1. 135-156.

Hunter-Crawley, Heather 2013. 'Divine Embodiment: Ritual, Art, and the Senses in LateAntique Christianity.' PhD Thesis. University of Bristol.

Hunter-Crawley, Heather 2017. 'Movement as Sacred Mimesis at Abu Mena and Qal'at Sem'an.' In Excavating Pilgrimage: Archaeological Approaches to Sacred Travel and 
Movement in the Ancient World, ed. Troels M. Kristensen, Wiebke Friese. Abingdon. 187-202.

Ingold, Tim 2000. The Perception of the Environment: Essays on Livelihood, Dwelling and Skill. London.

Knappett, Carl 2005. Thinking Through Material Culture: An Interdisciplinary Perspective. Philadelphia.

Knappett, Carl; Malafouris, Lambros (eds) 2008. Material Agency: Towards A NonAnthropocentric Approach. New York.

Lassus, Jean 1932. 'Images de Stylites', Bulletin D'études Orientales 2. 67-82.

Malafouris, Lambros 2008a. 'Between Brains, Bodies and Things: Tectonoetic Awareness and the Extended Self', Philosophical Transactions of the Royal Society B: Biological Sciences 363, no. 1499. 1993-2002.

Malafouris, Lambros 2008b. 'Is It “Me” or Is It “Mine”? The Mycenaean Sword as a Body-Part.' In Past Bodies, ed. Dušan Boric, John Robb. Oxford. 115-123.

Malafouris, Lambros; Renfrew, Chris (eds) 2010. The Cognitive Life of Things: Recasting the Boundaries of the Mind. Cambridge.

Menze, Volker 2015. 'The Transformation of a Saintly Paradigm: Simeon the Elder and the Legacy of Stylitism.' In Religious Identities in the Levant from Alexander to Muhammed: Continuity and Change, ed. Michael Blömer, Armin Lichtenberger, Rubina Raja. Turnhout. 213-226.

Merleau-Ponty, Maurice [1945] 2002. Phenomenology of Perception. London.

Peña, Ignacio 1996. The Christian Art of Byzantine Syria. Madrid.

Peña, Ignacio; Castellana, Pascal; Fernández, Romuald 1975. Les Stylites syriens. Publications du Studium Biblicum Franciscanum, collectio minor 16. Milan.

Pentcheva, Bissera 2010. The Sensual Icon: Space, Ritual, and the Senses in Byzantium. University Park.

Rahmani, Levi Y. 1999. 'The Byzantine Solomon “Eulogia” Tokens in the British Museum', Israel Exploration Journal 49. 92-104.

Renger, Almut-Barbara; Stellmacher, Alexandra 2010. 'Der Asketen- als Wissenskörper: Zum verkörperlichten Wissen des Simeon Stylites in ausgewählten Texten der Spätantike', Zeitschrift für Religions- und Geistesgeschichte 62. 313-338.

Schachner, Lukas A. 2010. 'The Archaeology of the Stylite.' In Religious Diversity in Late Antiquity, ed. David M. Gwynn, Susanne Bangert. Leiden. 329-397.

Sodini, Jean-Pierre 1989. 'Remarques sur l'iconographie de Syméon l'Alépin, le premier stylite', Monuments et mémoires de la Fondation Eugène Piot 70. 29-53.

Sodini, Jean-Pierre 2010. 'L'influence de Saint-Syméon dans le culte et l'économie de l'Antiochène.' In Les Sanctuaires et leur rayonnement dans le monde méditerranéen de l'Antiquité à l'époque moderne, ed. Juliette de la Geniere, André Vauchez, Jean Leclant. Paris. 298-301.

Sodini, Jean-Pierre; Biscop, Jean-Luc 2011. 'Qal'at Sem'an et Deir Sem'an: Naissance et développement d'un lieu de pèlerinage durant l'antiquité tardive.' In Architecture Paléochrétienne, ed. Jean-Michel Spieser. Gollion. 11-59.

Stang, Charles M. 2010. 'Digging Holes and Building Pillars: Simeon Stylites and the “Geometry” of Ascetic Practice', Harvard Theological Review 103. 447-470.

Steiner, Shannon P. 2011. 'Agent of Touch and Transformation: A Pilgrimage Token of Saint Symeon the Younger in the Menil Collection.' Master of Arts Dissertation. University of Texas at Austin. 
Todd, Zoe 2016. 'An Indigenous Feminist's Take on the Ontological Turn: “Ontology” Is Just Another Word for Colonialism', Journal of Historical Sociology 29. 4-22.

Vikan, Gary 2003. Sacred Images and Sacred Power in Byzantium. Aldershot.

Vikan, Gary 2010. Byzantine Pilgrimage Art. Revised. Washington.

Wright, G.R.H. 1970. 'The Heritage of the Stylites', Australian Journal of Biblical Archaeology 1. 82-107.

Yasin, Ann Marie 2017. 'The Pilgrim and the Arch: Paths and Passageways at Qal'at Sem'an, Sinai, Abu Mena, and Tebessa.' In Excavating Pilgrimage: Archaeological Approaches to Sacred Travel and Movement in the Ancient World, ed. Troels M. Kristensen, Wiebke Friese. Abingdon. 166-186. 